\title{
Modified Digital Comics: An Alternative Way for Enhancing Students Narrative Text Writing Ability
}

\author{
Tri Widioko
}

Master’s Degree of English Education, University of Lampung, Indonesia

\begin{abstract}
One of the countries in the world with the most comic readers is Indonesia. Based on Detik.com, Indonesia as the biggest southeast comic market has more than 6 million active users. This phenomenon becomes an opportunity for applying this media in the classroom. The purposes of this study are to find out the effect of modified digital comic as an alternative way in improving the students' ability in writing narrative text and what aspect of writing which is influenced by this media. This research used quantitative approach and was conducted to 29 students. For collecting the data, the researcher administered the writing test. This study showed that there was a significant improvement of students who have low proficiency in the English language in writing narrative text after using modified digital comics as a languagelearning media. However, the teacher perceived the use of modified digital comics in the classroom as time consuming and impractical.
\end{abstract}

Keywords: modified digital comic, narrative text, writing ability

\section{INTRODUCTION}

In English, there are four skills of language which are compulsory to be learned by learners, namely listening, speaking, reading, and writing. Reading and listening involve receiving information and so they are called the receptive skills. Speaking and writing are known as the productive skills because they involve producing words, phrases, sentences and paragraphs. The purpose of mastering four skills of language is to develop the ability to communicate in oral and written form maximally. Notwithstanding, to achieve good and maximum communication function, students not only need skills, but also knowledge.

Achieving the four basic skills, especially writing, have so many benefits. One of them is making students able to express their idea to other people logically in written form. However, many students find difficulty in writing. One of the main problems among students is the fact that many of them cannot develop their writing skills, mostly the ones who are making compositions in a foreign language (Aragon, 2013). Moreover, many students find difficulty when writing because they do not know how to start writing the topic that they should choose. As Aragon (2013) concludes that students generally come to write English composition without any idea about organizing their ideas, even in their mother tongue.

Richards and Renandya (2002: 303) states that from the four language skills which are taught at schools, writing is the most difficult skill for language learners to master. The difficulties are in generating and organizing ideas as well as in translating the idea into readable text. In addition, Ghaith (2002) says that writing is a complex process where the writers are allowed to explore thoughts and ideas and make them visible and concrete. In writing, a writer will be involved in the process of building large units of ideas. They will be linked to form sentences.

Furthermore, Sampath and Zalipour (2010) state that students consider writing to be an extremely difficult area in learning English and it seems to be a daunting task 
for most ESL learners. They believe that students are not aware of writing skills and they are usually not motivated to write in English. According to the National Commission on Writing (2004), writing well is a vital skill for academic or occupational success, but one that is especially difficult for second-language learners to master. Writing narrative text is also not easy for the student (Kharisma, 2009). Hence, English teachers need to find an alternative way to help students in improving their skills.

Referring to the reasons above, where most experts state that writing skill, especially in writing narrative text is difficult to master, teachers, should find the alternative way to solve it and make teaching and learning writing fun and enjoyable. To make teaching writing subjects more interesting, fun, and enjoyable, appropriate and good media are needed. In the teaching-learning process, the teacher uses media that hopefully can help students to improve their writing ability. According to Munadi (2008), to select the appropriate media, the teacher must consider the characteristics of the students, which directly relate to the learning process. Teachers should choose what appropriate media which are suitable for their students' condition or situation.

In the writing of the narrative text, students' creativity and imaginations should be triggered to make them produce better writing. In writing class, especially in the writing of the narrative text, the use of visual images - in this case, picture series of sequential pictures in the form of modified digital comic, mean a lot for students. They are helped at least in one sense: developing their creativity and imagination.

One way to help student's problems in writing narrative text is by using digital comics (Yunus et al., 2015, pp.54-55). Yunus and Friends (2015, p.54) say that digital comics can spur students' interest to write. By using digital comic, students can work collaboratively as a digital comic can be a great collaboration tool (Yunus et al.,
2015, pp.54- 55). This media subsequently can improve students' language skills.

Moreover, one of the countries in the wold with the most comic readers is Indonesia. Based on Detik.com, Indonesia, as the biggest southeast comic market, has more than 6 million active readers. Consequently, this phenomenon becomes a big opportunity for us in applying this media in the classroom. But the question is what we should do to these comics.

Nowadays, there are two types of comics. A comic can be seen as a printed comic which is found in comic books for instance, and also digital comics that are in digital media. Digital comics can be used as pedagogical tools and it involves the application of Information and Communication Technologies (ICT). Today, many teachers also prefer to utilize ICT in teaching and learning, due to the advantages that it offers, especially in creating and engaging learning environment (Melor, Maimun, and Lin, 2009; Maimun et al., 2009; Roberto, 2007). The computer provides interactive audio and visual technology which helps the user to make the teaching and learning process fun, interactive and cooperative, as well as effective in passing on linguistic instruction (Brown, 2001). Neo (2004) claims that ICT has had a significant impact and has influenced teachers in the development of new perspectives and innovative teaching techniques. Teachers use technology throughout their work and not just as part of the teaching and learning process (Melor and Lin, 2009; Maimun et al., 2009). Moreover, the use of technology enables students to use both the language and the technology (Melor, 2007). According to Wang (2002), the broadening of a teacher's perspective on education is a particularly valuable indicator of his or her ability or desire to implement the use of technology in the classroom.

Digital comic is a digital media that can be used in the classroom to help the students' understanding by using pictures in the story (Kustianingsari and Dewi, 2015, 
p.1). Digital media has some characteristics (Smaldino et al., as cited in Purnama, Mulyoto and Ardianto, 2015, p.20); first, it is easy to use, because of its digital projector. Second, it is portable, it can be carried anywhere. Third, the ability to save of this media, digital visual can be stored on a CD, DVD, flash disk, external hard disk, etc. The last, the endurance of the media, the digital media can be saved in a long time.

Digital comics are useful in a variety of teaching and training settings (Berkowitz and Packer, 2001). Zimmerman (2010) reports that an effective and efficient way to strengthen students' emerging facility in the English language is to narrate stories using comic strips. Telling stories by building comic strips has similarly been proven to make the language-learning process a much more enjoyable experience. Zimmerman (2010) has also emphasized the fact that online comics are an effective resource to help students to be creative, reduce anxiety and have fun during the acquisition of a new language, as well as enabling them to master the language in a short period. Research shows that online comics, such as webcomic strips, webcomic books, and cartoons, are a valuable learning resource for informal assessment, motivating and enabling students to exchange their ideas and construct knowledge collaboratively, as well as promoting learners involvement and motivation (Saraceni, 2003; Tatalovic, 2009; Varnum and Gibbons, 2001; Kannenberg, 2002; Khordoc, 2001; Yang, 2003).

To conclude, applying digital comics is a positive way to attract learners, it can help and motivate the learners. Digital Comics are more suitable and more effective in this era (4.0) to use in the teaching and learning process. Moreover, by using a digital object, teachers do need to print out so many papers when they will teach in the class (paperless). But, most researches in the implementations of comics in the classroom, only use the original comics and there is no editing there. It is only taking and giving. Though the result of using comic or digital comics in the classroom is good and has a positive impact, there will be some weaknesses if there is no editing in the comic. As an example, sometimes there are some words or statements that are inappropriate or too vulgar stated in the panels of comics (Lestari et al, 2009). Consequently, the teacher should erase or modify the words or statements in the comics to be more suitable and appropriate with the students' age level. Moreover, language use in the comic needs to be considered. Sometimes grammar is not good in the comics. So, the use of digital comics in teaching writing of narrative text can make students speak inappropriately (Lestari et al. 2009). Slang words such as "bang!”, “whap”, “crack!”, "boom" etc. appeared in the digital comic and there is no meaning in the dictionary. In addition, the picture of the digital comic which is used in the teaching-learning process sometimes needs to be modified. For example, we can modify or give some blur on the digital comic pictures which have a character that uses inappropriate clothes in the scene. It is needed to make the comic more suitable for Indonesian culture in general. In modifying the digital comics, the teacher can use or download free applications from the internet, such as Adobe Photoshop, Corel, etc. By the statements above, the researcher conducted a research by using modified digital comics in an experimental research entitled Modified Digital Comics for Enhancing Students Narrative Text Writing Ability.

\section{METHOD}

The objectives of this research were to find out the improvement of students' ability in writing narrative text due to the use of modified digital comic and which aspects of writing skill that were improved by using this media. This research was quantitative research which used pretest posttest design. In this research, the researcher took the students in the second grade of SMAN 1 Gadingrejo which 
consisted of seven classes as the population. Each class consisted of about 30 students. Their ages were in the range of 15 until 18 years old. The researcher used one class only from the population as the sample. Researcher used XI MIPA 6 as the sample of this research. The reason for choosing one class only was because this research contained modification elements for digital comic as a medium in teaching and learning process. It was assumed that the modified digital comic would be better than unmodified digital comic and it no control class needed as a comparison. So, researcher took one class only as the experimental class.

The research was conducted in five meetings. At the first meeting, the researcher gave the pre-test to the students in order to know how far students' ability in writing narrative text. After conducting the pre-test, the researcher conducted treatment by using modified digital comic in three meetings. The treatments were done for helping and stimulating students in order to improve their ability in writing narrative text. In the last meeting, the researcher conducted the post-test to the students after they had been taught by using modified digital comic. Like the first meeting, the students made a narrative text they know within 60 minutes. After getting the pre-test and the post-test, the researcher analyzed the result between the pre-test and the posttest. The researcher examined the students' score by using T-test of Statistical Package for Social Science (SPSS) for windows to see whether there was an improvement or not and also how far the improvements.

\section{RESULT}

\section{The Distribution of Students' Score in Pretest}

\begin{tabular}{|l|l|l|l|l|l|l|l|}
\hline Interval Score & Frequency & Percentage & Mode & Median & The Lowest Score & The Highest Score & Average Score \\
\hline $35-40$ & 3 & $10.3 \%$ & & & & & \\
\hline $41-45$ & 7 & $24.1 \%$ & & & & & \\
\hline $46-50$ & 3 & $10.3 \%$ & & & & & \\
\hline $51-55$ & 5 & $17.2 \%$ & & & & & \\
\hline $56-60$ & 4 & $13.8 \%$ & & & & & \\
\hline $61-65$ & 3 & $10.3 \%$ & & & & & \\
\hline $66-70$ & 4 & $13.8 \%$ & & & & & \\
\hline Total & 29 & $100 \%$ & 56.50 & 53.00 & 35.00 & 69.50 & 52.16 \\
\hline
\end{tabular}

Beside the distribution score in each aspect, the researcher also found out the distribution of final score in pre-test. From the table above, it could be seen that scores the students were various. It could be seen that there were 3 students (10.3\%) who got score in the range 35-40, 7 students (24.1\%) who reached score in the range 41-45, 3 students $(10.3 \%)$ who reached score in the range 46-50, 5 students (17.2\%) who reached score in the range 51-55, 4 students who reached score in the range 56-60, 3 students got score in the range 61-65 and 4 students who got score in the range 66-70.

\section{Distribution of Students' Score in Pretest}

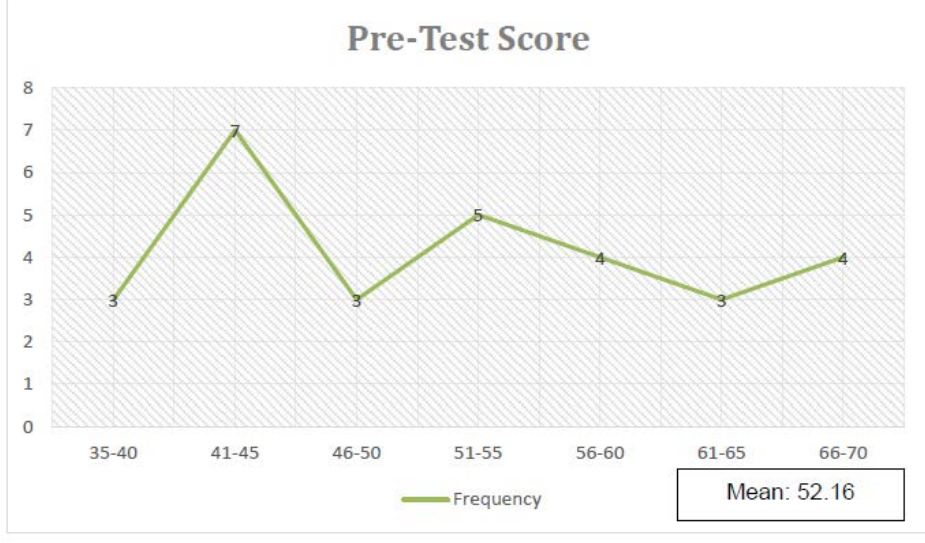


The table 4.6 also showed us the distribution of students' lowest, highest, and average score in pre-test. The highest score was 69.50 and the lowest score was 35.00 and the average score of pre-test was 52.16.
Based on the result above, we could see that the mean score of content aspect was 10.74, language use aspect was 10.55, organization aspect was 10.43 , vocabulary aspect was 10.40, and the mechanic aspect was 10.03 .

\section{The Distribution of Students' Score in Posttest}

\begin{tabular}{|l|l|l|l|l|l|l|l|}
\hline Interval Score & Frequency & Percentage & Mode & Median & The Lowest Score & The Highest Score & Average Score \\
\hline $61-65$ & - & $0 \%$ & & & & & \\
\hline $66-70$ & 2 & $6.90 \%$ & 74.5 & 77 & 68.5 & 91.5 & 78.31 \\
\hline $71-75$ & 10 & $34.50 \%$ & & & & & \\
\hline $76-80$ & 7 & $24.10 \%$ & & & & & \\
\hline $81-85$ & 6 & $20.70 \%$ & & & & & \\
\hline $86-92$ & 4 & $13.80 \%$ & & & & & \\
\hline Total & 29 & $100 \%$ & 74.5 & 77 & 68.5 & 91.5 & 78.31 \\
\hline
\end{tabular}

After conducting the pretest and three times treatments, the researcher administered the posttest. The researcher conducted post-test in order to find out whether modified digital comic could be used in the classroom to improve students' ability in writing narrative text or not. The scoring system and the scoring criteria were exactly same as the pre-test. From the table above, it could be seen that scores the students were various. It could be seen that there were 2 students (6.9\%) who got score in the range 66-70, 10 students (34.5\%) who reached score in the range $71-75,7$ students (24.1\%) who reached score in the range 7680, 6 students $(20.7 \%)$ who reached score in the range $81-85$, and 4 students (13.8\%) who reached score in the range 86-92.

\section{Distribution of Students' Score in Posttest}

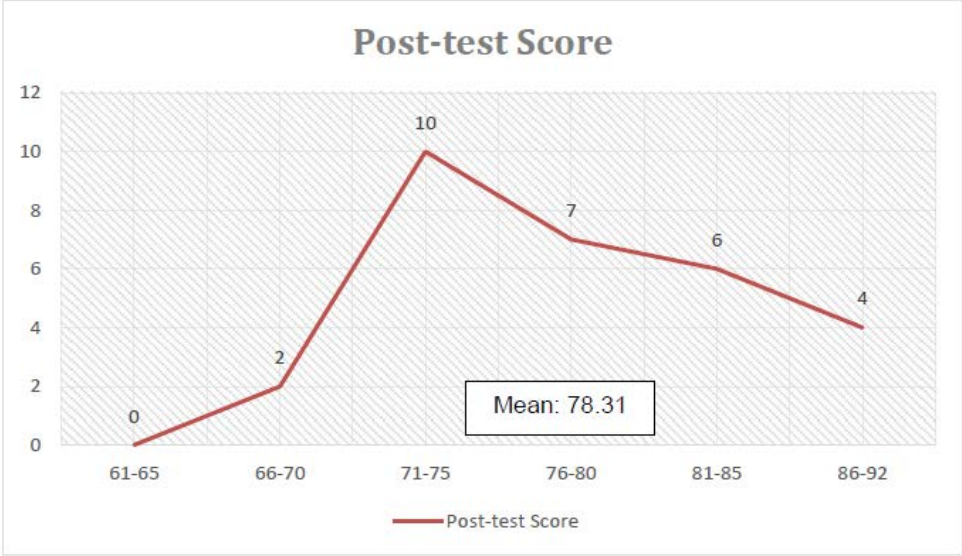

The table also showed us the distribution of students' lowest, highest, and average score in post-test. The highest score was 91.50 and the lowest score was 68.50 and the average score of post-test was 78.31. Based on the result above, we could see that the mean score of content aspect was 15.79, language use aspect was 15.72, organization aspect was 15.72 , vocabulary aspect was 15.97, and the mechanic aspect was 15.10.
Improvement of Students' Achievement in Writing Narrative Text

\begin{tabular}{|l|l|l|l|l|}
\hline $\begin{array}{l}\text { Aspect of } \\
\text { Writing }\end{array}$ & $\begin{array}{l}\text { Pretest } \\
\text { Score (PrS) }\end{array}$ & $\begin{array}{l}\text { Posttest } \\
\text { Score (PoS) }\end{array}$ & $\begin{array}{l}\text { Maxi } \\
\text { mum } \\
\text { Score } \\
\text { (Ms) }\end{array}$ & $\begin{array}{l}\text { Aspects } \\
\text { Improv } \\
\text { ement } \\
\text { (PoS } \\
\text { PrS) }\end{array}$ \\
\hline Content & 10,74 & 15,79 & 20 & 5,05 \\
\hline $\begin{array}{l}\text { Language } \\
\text { Use }\end{array}$ & 10,55 & 15,72 & 20 & 5,17 \\
\hline $\begin{array}{l}\text { Organizatio } \\
\text { n }\end{array}$ & 10,43 & 15,72 & 20 & 5,29 \\
\hline Vocabulary & 10,40 & 15,97 & 20 & 5,56 \\
\hline Mechanic & 10,03 & 15,10 & 20 & 5,07 \\
\hline Total & 52.16 & 78.31 & 100 & 26.14 \\
\hline
\end{tabular}


The table and figure on the graph showed the improvement of the students' writing skill in the pretest and posttest in each aspect in writing. In the pretest, it could be seen that the mean of content was 10.74 because when the researcher conducted the pretest, the researcher found that many students had limited knowledge of subject, little substance, and inadequate development of topic in their text. Moreover, sometimes some students also did not show knowledge of the subject, their texts were not enough to evaluate, for example,

One day in the Jungle there was many animals si kancil, bufalo, turtle, tupai. One day Si kancil and turtle berebut eat $\mathrm{Si}$ kancil not accept and invite turtle for Join event and that wining the competition will got eat. run Competition was started and the winner was the turtle.

The text above was narrative text which was written by student. From the text above, it could be seen that the student only could write little substance, and inadequate development of topic so that student made impertinent narrative text. There was something missing in the story line of the text, for example in the sentence "run Competition was started and the winner was the turtle." It was very short and needed to be added what happened in the competition which made the character in the story win the competition.

In the result of post-test, the mean score of content was 15.79. The improvement was 5,05. It was because most of the students could write adequately development of topic, for example,

\section{Talaga Warna}

One day, the princess celebrated her $17^{\text {th }}$ birthday party. Many people gathered in the palace. Then, Prabu took out a necklace which was made from gold and jewel. "My beloved daughter, today I give you this necklace. Please wear this necklace" said Prabu. "I don't to wear it, It's ugly" shouted the princess. Then she threw the necklace. The beautiful necklace was broken. The gold and jewels are spread out on the floor. Everybody couldn't say anything. They never thought their beloved princess would do that cruel thing. In their silence, people heard the queen crying. Every woman felt sad and began crying too. Then, everybody was crying.

Suddenly, from the underground, a spring emerged. It made a pool of water. Soon, the place became a big lake. The lake finally sank the kingdom. On a bright day, the lake full of color. These colors come from shadows of forest, plants, flowers, and sky around the lake. Nowadays, people called the lake "Talaga Warna” it means "Lake of color".

By looking the narrative text above, it could be seen that student could write smoothly enough. The words and sentences were better than in the pretest. It was because the text was fulfill the criteria of content aspect like some knowledge of the subject, adequate range, mostly relevant to the topic but lacks detail. It meant that there was an improvement in students' writing narrative text in content aspect. This improvement meant modified digital comic could be used as a medium in teaching writing narrative text.

Then, the mean score of language use in pretest was 10.55. Most of students had problem in constructing correct sentences. It was because when the students made a sentence, they still found some difficulties to understand the pattern or the use of subject, verb, and how they arranged the sentence itself. There was major problem in simple/complex construction, frequent errors of negation, word order, and sometimes had meaning confusion. For example,

One day, lived monkey and crocodille. The crocodille want to eat bananas, but he don't get it. Than, crocodille look a monkey is eating bananas. So crocodille said help to monkey, he said "hey monkey can you help me". "What can I help crocodille" answer monkey. "Can you give me the bananas" 
In post-test, the result of language use was 15.72. The improvement was 5,17. It was found that many students could write sentences effectively, good construction enough, and minor problems, for example, The mouse deer caught all those bananas quickly and ran, left the monkey while said "Thank You! Now all your bananas are mine!". But, there were some students that still had several mistakes in using verb, preposition, for instance.

Organization aspect in pre-test was 10.43. It was because many students had lacks of logical sequence and development, non-fluent, and the idea in their text was confusing, for example,

\section{SANGKURIANG}

Once upon live in a family. Couple name Tumang and wife and he have son a name Sangkuriang. One day Sangkuriang and Tumang go to forest for taking food. But, because they can't food, Sangkuriang tired and he shoot tumang. In home mother know tumang in shoot with Sangkuriang and Sangkuriang go from home.

Someday Sangkuriang with mother meet. They falling in love, but mother know he Sangkuriang. So, mother give a message for Sangkuriang for build candi for she. And then Sangkuriang build candi with devil. Because mother know will finish she make plane for sabotace Sangkuriang and Sangkuriang fail build candi.

The mean score of organization in post-test was 15.72 . The improvement was 5.29. It meant that there was an improvement in students' narrative text writing ability in organization aspect. Generally, many students wrote fluently enough in expressing ideas, but sometimes their text was somewhat choppy, loosely organized but the main idea stood out and was logical but incomplete sequencing. So, this improvement means modified digital comic could be used as media in teaching writing narrative text.

\section{"Surabaya”}

At one time there lived two strong animals. They were Sura the shark and Baya the crocodile. Two lived together in a river in a dense frorest. These two animals had an equation that was to eat greedily.

Due to the gluttony various foods such as small fishes, crabs and shrimps continued to decrease. Finally, Sura and Baya lacked foods.

Once upon a time Baya went down to the river in search of food close to Sura. Sura got angry, and finally there was a fierce fight. Since they were equally strong the no one won.

Finally, they both decided to divide the river into who upstream for Baya while downstream for Sura. Sometime later there was a prolonged dry season. The water downstream was getting less and less which made Sura difficult to get food. This was know to get food. Finally, Sura went downstream to look for the food this was known to Baya and in the end there was a violet fight between the two. This caught the attention of many people and watched the fight.

Baya and Sura are both strong and this cause both animals to die. An old man then said " From today I call this place Surabaya in memory of this unsual event" People who witnessed this accepted the old mans statement. From then on it was known as the Surabaya area.

Vocabulary was 10.41 in pre-test. The researcher found that many students wrote in limited range. They had frequent errors in choosing words, and meaning was confusing and obscure, for example, So, mother give a message for Sangkuriang for build candi for she. And then Sangkuriang build candi with devil. Because he mother know will finish she make plane for sabotace Sangkuriang and Sangkuriang fail build candi.

The mean score of vocabulary in post-test was 15.97. The improvement was 5.56. It meant that there was an improvement in students' narrative text writing ability in vocabulary aspect. Researcher found that students' texts in 
vocabulary aspect had already adequate range, occasional errors but meaning not obscured, for example, "The Strongest Monster came up from the gate, he looked small and different than the other monsters. But Chriss who had a lot of experiences realize that small monster was a thousand times stronger than monsters that Chriss had ever fought before."

He believed in himself that he would be able to beat the monster away. The day where the fight between Chriss and the monster finally came. They fought so far away from where the people live.

The last was mechanic. The mean score of mechanic aspect in pre-test was 10.03. Researcher found that many students had occasional errors of punctuation, spelling, and capitalization in their narrative text, for example:

a Beatiful girl, eating an apple from a grandmother. After eating an apple, she is sleeping all the time."
The mean score of mechanic in posttest was 15.10. It meant that there was an improvement of students' narrative text writing ability in mechanic aspect. Researcher found that many students had few mistakes of punctuation and capitalization in their narrative text, for example:

One day, he got mad at Tumang for not pursuing the animals. Because of so angry, he then expelled Tumang so the dog went to the woods.

From the explanation above, it could be concluded that modified digital comic gave positive impact in improving students' narrative text writing ability in five aspects of writing. The improvement could be seen from the mean of pre-test and post-test, it ranged from 52.16 up to 78.31. This improvement meant that modified digital comic could be used as an alternative medium in teaching writing especially in teaching narrative text.

\section{The Significant Difference Between The Pretest and The Posttest}

\begin{tabular}{|c|c|c|c|c|c|c|c|c|c|c|}
\hline & \multicolumn{5}{|c|}{ Paired Differences } & \multirow[t]{3}{*}{$\mathbf{t}$} & \multirow[t]{3}{*}{ df } & \multirow{3}{*}{$\begin{array}{l}\text { Sig. (2- } \\
\text { tailed) }\end{array}$} \\
\hline & & & \multirow[t]{2}{*}{ Mean } & \multirow[t]{2}{*}{$\begin{array}{l}\text { Std. } \\
\text { Deviation }\end{array}$} & \multirow[t]{2}{*}{$\begin{array}{ll}\text { Std. } & \text { Error } \\
\text { Mean } & \end{array}$} & \multicolumn{2}{|c|}{$\begin{array}{l}\text { 95\% Confidence Interval of the } \\
\text { Difference }\end{array}$} & & & \\
\hline & & & & & & Lower & Upper & & & \\
\hline $\begin{array}{l}\text { Pair } \\
1\end{array}$ & $\begin{array}{l}\text { Pretest } \\
\text { Posttest }\end{array}$ & - & $-26,15517$ & 7,91822 & 1,47038 & $-29,16710$ & $-23,14324$ & $-17,788$ & 28 & ,000 \\
\hline
\end{tabular}

\section{DISCUSSION}

Based on the result of the research, the researcher could see that the students' ability in writing narrative text had increased due to the use of modified digital comic. This result was similar to the previous research about the use of digital comic conducted by Susilawati (2017), which stated that the use of digital comic as teaching media could improve students' writing skill. The digital comic has been proven as an effective media to improve students' writing ability in writing narrative text. This result was supported statistically by the computation of t-test using IBM SPSS Statistics. In addition, the students also felt more enjoyable and enthusiastic when they were taught by using digital comic. It was because the pictures in the frames positively added many visual cues to the story line for helping students in generating, developing and understanding of the story.

By looking the explanation above, here is an important illustration of the difference between result of the pre-test and the post-test based on the aspects of writing as follows:

\section{a. Content}

In the treatment of the research, most of students gave positive responses through the use of the modified digital comic as a medium in teaching writing of narrative text. In making the narrative text especially in generating the ideas, students were helped by using the sequence pictures in the modified digital comic. As we know that the modified digital comic has 
sequence pictures in the frames which can add many visual cues to the story line for helping students in generating, developing and understanding of the story line. The statement was in line with Hornby (1973) who states that series of picture are really serviceable in teaching writing because they provide complete ideas to stimulate students' imagination. Moreover, using comic as teaching aids in classroom activities can improve students' creativity and imagination in writing (Listyani, 2019). Dealing with motivation, the students did not feel learning English as a frightening and boring subject since the learning atmosphere in classroom was more joyful, so the students could make or develop the text easier, especially by using modified digital comic.

\section{b. Language Use}

Language use is the next aspect that was measured in this research. Language use refers to the use of correct grammatical and syntactic pattern on separating, combining and grouping idea in words, phrases, clauses, and sentences to bring out logical relationship in the text. In the treatment by using modified digital comic, students were forced to practice writing narrative text for several times with correct sentences according to grammatical correctness and syntactic pattern. In the treatment, teacher also provided some additional lesson about how to use past tense in the text. By doing these activities, students be trained to write narrative text well based on modified digital comic that they use. Related to the finding, the researcher found that the problem in writing narrative text was the lack of knowledge for using the appropriate tense. In the result of pre-test, the students' grammar showed various errors. After the treatment, their knowledge of grammar was improved. It could be seen in the result of post-test that they used good grammar in their narrative text writing.

\section{c. Organization}

Organization refers to the logical organization of the content (coherence and cohesive). This term relates to sentences which are arranged logically and flow smoothly. Logical arrangement refers to the order of the sentences and ideas. The ways to order the sentences depend on the purposes. At first, students felt difficult in generating ideas. Many students had lacks of logical sequence and development, nonfluent, and the idea was confusing in their text. To overcome the problems, the student looked at the sequence pictures in the modified digital comic, so that they could get keyword about what the next events and expanded their imagination. Modified digital comic gave the clue of chronological events to the students. It could help students to generate ideas easily based on the visualizations contained in the modified digital comic. The use of modified digital comic in the treatment was actually meant to help students imagine the story line and also enable the students to understand about identifying the elements of story (for instance: characters, plot, theme) through events and sequential pictures in the modified digital comic. That is why modified digital comic can improve students' achievement in organization aspect.

\section{d. Vocabulary}

The next aspect is vocabulary. Vocabulary refers to the selection of words which are suitable with the content in order to convey the idea to the readers effectively. In the result of post-test, the students' vocabulary had been improved. When the students arranged the story based on modified digital comic, they were looking for the words that they did not know in dictionary seriously and joyfully for completing and arranging the sentences. Generally, most of them used vocabulary which was suitable and appropriate to the context. It meant that, the students were able to understand how to use the suitable words to their writing. So, even though in the 
modified digital comic there were no many words, students could be triggered to find suitable words for their narrative text.

\section{e. Mechanic}

The last aspect is mechanic. Mechanic refers to the use of conventional graphic of the language, examples; the steps of arranging letters, words, paragraphs by using knowledge of structure. In the first meeting the researcher found that many students had some errors of punctuation, spelling, and capitalization in their narrative text. It was different with the result in posttest. In post-test, many students had few errors of punctuation, spelling, and capitalization in their text. There was an improvement in students' narrative text writing ability in mechanic aspect.

From the result, it can be seen that vocabulary has the highest improvement. It was 5.56. Organization aspect has 5.29 of improvement, language use has 5.17 of improvement, while mechanic has 5.07 of improvement and the last content has 5.05 of improvement. Based on the data and the explanation above, it could know that the students' ability in writing narrative text in the second grade of SMAN 1 Gadingrejo had improved in all aspects and teaching learning process run well through the use of the modified digital comic. This result was in line with the previous research conducted by Susilawati (2017). Though, she used which stated that the use of digital comic as teaching media could improve students' writing skill. The digital comic has been proven as an effective media to improve students' writing ability in writing narrative text. In addition, the students also felt more enjoyable and enthusiastic when they were taught by using digital comic. The result also supported a research conducted by Megawati (2012) which stated that the use of comic as teaching media in teaching writing could improve writing ability especially in writing narrative text in all aspects namely, content, language use, organization, vocabulary, and mechanic.
From the result of this research, it could be said that modified digital comic was useful for students in learning narrative text writing. Modified digital comic had sequence pictures in the frames which could add many visual cues to the story line for helping students better in generating, developing and understanding of the story. The statement was in line with Hornby (1973) who stated that series of picture are really serviceable in teaching writing because they provide complete ideas to stimulate students' imagination. Finally, it could be concluded that students' ability in writing narrative text improved due to the use of modified digital comic. It was not only in content and organization aspect, but also in all aspects. It also might be said that modified digital comic was applicable and suitable for high school students to improve their ability in writing narrative text.

\section{CONCLUSION}

Referring to the discussion of the research findings, the researcher comes to these following conclusions as follows: (1) There is improvement of students' ability in writing narrative text from the pretest and the posttest due to the use of modified digital comic. Modified digital comic is an alternative way for teaching writing especially in writing narrative text which can improve students' skill in five aspects of writing; namely content, language use, organization, vocabulary, and mechanic. (2) By using modified digital comic, students' confusion in writing could be avoided. It gives students many visual cues for helping them in composing the narrative text, so it makes students easier in following the teaching learning process. Modified digital comic is good media which can be used by the teacher to help the students more understand about the narrative text. By using modified digital comic, students can learn how to write narrative text smoothly.

Considering to the finding of the research, the researcher would like to recommend some suggestions as follow: (1) Since teaching writing narrative text by 
using modified digital comic can give better result for students, the researcher suggests the teachers to use it as media in teaching writing narrative text. (2) The researcher used modified digital comic to improve students' ability in writing narrative text in senior high school. Further research can use modified digital comic for other kinds of text such as recount text and for different levels of students. Further research also can try to use modified digital comic for improving students' ability in another skill of English such as speaking skill. Finally, this research also can be a reference for another research who wants to conduct research about writing especially in narrative text writing by using modified digital comic

\section{Conflict of Interest: None}

\section{REFERENCES}

1. Aragón Jiménez, C. A., Baires Mira, D. C., \& Rodriguez, G. S. (2013). An analysis of the writing skill difficulties of the English Composition I students at the Foreign Language Department of the University of El Salvador. Undergraduate work, retrieved from http://ri.ues.edu.sv/5519.

2. Berkowitz, J. and T. Packer, 2001. Heroes in the classroom: Comic books in art education. Art Educ., 54(6): 12-18.

3. Brown, H.D., 2001. Teaching by Principles: An Interactive Approach to Language Pedagogy. $2^{\text {nd }}$ Edn., Addison Wesley Longman, Inc., New York, Retrieved form: http://www.cuhk. edu.hk/ ajelt/vol8/rev1.htm

4. Comics. 2010. In Oxford Advanced Learner (8th Ed.). Oxford: Oxford University Press.

5. Comics. 2003. In Merriam-Webster's dictionary (11th Ed.). Springfield, MA: MerriamWebster.

6. Ghaith, Ghazi. 2002. Writing. Retrieved December 2nd, 2013, from http://www.thefreedictionary.com/writing.

7. Hornby, P. 1973. Intonation and syntactic structure in the development of presupposition. Paper presented at the Biennial Meeting of Society for Research in Child Development, Philadelphia.

8. Jack C. Richards and Willy A. Renandya. 2002. Methodology in Language Teaching:
An Anthology of current Practice. New York: Cambridge University Press.

9. Kustianingsari, Nadia, \& Dewi, Utari. 2015. Pengembangan media komik digital pada mata pelajaran Bahasa Indonesia tema lingkungan sahabat kita materi teks cerita manusia dan lingkungan untuk siswa kelas V SDN Putat Jaya III/379 Surabaya. A paper submitted to Fakultas Ilmu Pendidikan, Universitas Negeri Surabaya.

10. Listyani. 2019. The Use of a Visual Image to Promote Narrative Writing Ability and Creativity. Eurasian Journal of Educational Research 80 (2019) 193-224.

11. Lestari, Suci., Sukma Putri C., and Yuniarti. 2009. Media Grafis: Media Komik. Bogor: Jurusan Kurikulum dan Teknologi Pendidikan, Konsentrasi Perekayasa Pembelajaran, Fakultas Ilmu Pendidikan, Universitas Pendidikan Indonesia.

12. Maimun, A.L., A.E. Mohamed, M.Y. Melor, W. Ismail and N. Nor Azah, 2009. The application of multicultural education and applying ICT on Pesantren in South Sulawesi, Indonesia. WSEAS Trans. Inform. Sci. Appli., 6(8): 14011411.

13. Megawati, F. 2012. Comic strips: A Study on The Teaching of Writing Narrative Texts to Indonesian EFL students. Universitas Negeri Malang.

14. Melor, M.Y., 2007. Malaysian ESL teachers' use of ICT in their classrooms: Expectations and realities. RECALL: J. Eurocall, 9(1): 79-95.

15. Munadi, Y. 2008. Media Pembelajaran. Sebuah Pendekatan Baru. Ciputat: Gaung Persada Press

16. National Commission on Writing, 2004. Writing: A Ticket to Work...or a Ticket Out. The College Entrance Examination Board, New York.

17. Neo, M., 2004. Cooperative learning on the web: A group based, student centered learning experience in the Malaysian classroom. Austral. J. Educ. Techn., 20(2): 171-119.

18. Nisa, Fakhrun., \& Al-Hafidz, Muhd,. 2014. Teaching writing a narrative text by using comic creator (Bitstrip) as a medium to second-grade students. JELT, vol. 03 No. 1 Serie A, ISNN 2302- 3198, 72-77.

19. Sampath, D. and A. Zalipour, 2010. The Pedagogical potentials of Weblog in Developing Students' Writing Skills: ICT for Language Learning. R e t r i e v e d f o r 
$\mathrm{m}: \mathrm{h} \mathrm{t} \mathrm{t} \mathrm{p} \mathrm{:} \mathrm{/} \mathrm{/} \mathrm{w} \mathrm{w} \mathrm{w} \mathrm{.} \mathrm{p} \mathrm{i} \mathrm{x} \mathrm{e} \mathrm{l} \mathrm{-}$ online.net/ICT4LL2010/ common /download/ Proceedings_pdf/IBL04Sampath, Zalipour. pdf, 2010 BL04Sampath, Zalipour. Pdf

20. Saraceni, M., 2003. The Language of Comics. Intertext. London and New York: Routledge, pp: 110. Retrieved form: http://www. comicsresearch.org/ entries /saraceni.html

21. Susilawati, F. 2017. Teaching Writing of Narrative Text Through Digital Comic. Journal of English and Education. UPI. Retrieved from: URL: http://ejournal.upi.edu/index.php/L-

E/article/view/9939

22. Thacker, C., 2007. How to Use Comic Life insara the Classroom. Retrieved form: http://www.macinstruct. com/node/69.

23. Tatalovic, M., 2009. Science comics as tools for science education and communication: A brief, exploratory study. J. Sci. Commun., 8(4): 1-17.

24. Varnum, R. and C.T. Gibbons, 2001. The Language of Comics: Word and Image. University Press of Mississippi, Jackson, Retrieved form: http:// www. popmatters.com/pm/review/language-ofcomics.

25. Wang, Y., 2002. When technology meets beliefs: Preservice teachers' perceptions of the teachers role in the classroom with computers. J. Res. Techn. Educ., 35(1): 150161.

26. Yang, G., 2003. Strengths of comics in education. Comics in Education. Retrieved form: http://www. humblecomics. com/comicsedu/strengths.html.

27. Yunus, M Md., Salehi, H., and Embi, M.A. 2012. Effects of Using Digital Comics to Improve ESL Writing. Research Journal of Applied Sciences, Engineering and Technology 4(18): 3462-3469, 2012.

28. Zimmerman, B., 2010. Using digital comics for language learning. eLearn Magazine. Retrieved form: at: http:/ /elearnmag. acm. org/ archive. $\mathrm{cfm}$ aid $=1710033$.

How to cite this article: Tri Widioko. Modified digital comics: an alternative way for enhancing students narrative text writing ability. International Journal of Research and Review. 2021; 8(12): 344-355. DOI: https://doi.org/10. 52403/ijrr.20211243 